\title{
Age and evolution of the lithospheric mantle beneath southern Baffin Island, Nunavut, Canada
}

\author{
Jingao Liu ${ }^{1,2}$, D. Graham Pearson'2, Garrett A. Harris' ${ }^{2}$, Maya G. Kopylova ${ }^{3}$, Erica Tso ${ }^{3}$ \\ ${ }^{1}$ China University of Geosciences, Beijing, China, jingao@cugb.edu.cn \\ ${ }^{2}$ University of Alberta,Edmonton,Canada,dgpearso@ualberta.ca, gaharris@ualberta.ca \\ ${ }^{3}$ University of British Columbia, Vancouver,Canada, mkopylov@eos.ubc.ca, etso@eos.ubc.ca
}

\section{Introduction}

In southern Baffin Island, Canada, the terrane known as the "Hall Peninsula Block" (HPB; Fig. 1) has an equivocal tectonic origin, poorly constrained from studies of crustal rocks (e.g., Scott, 1999; Connelly et al., 2006; Berman et al., 2013). Little is known about the age and composition of the deep mantle lithosphere beneath this area and such knowledge could help in terms of unravelling the origin of this terrane. The newly discovered diamondiferous Chidliak kimberlite province that was emplaced into the HPB (Fig. 1) in the Jurassic carried with the abundant mantle xenoliths. To help unravel the puzzling provenance of the Hall Peninsula Block, we undertook a Re-Os isotope and PGE study of these mantle xenoliths.

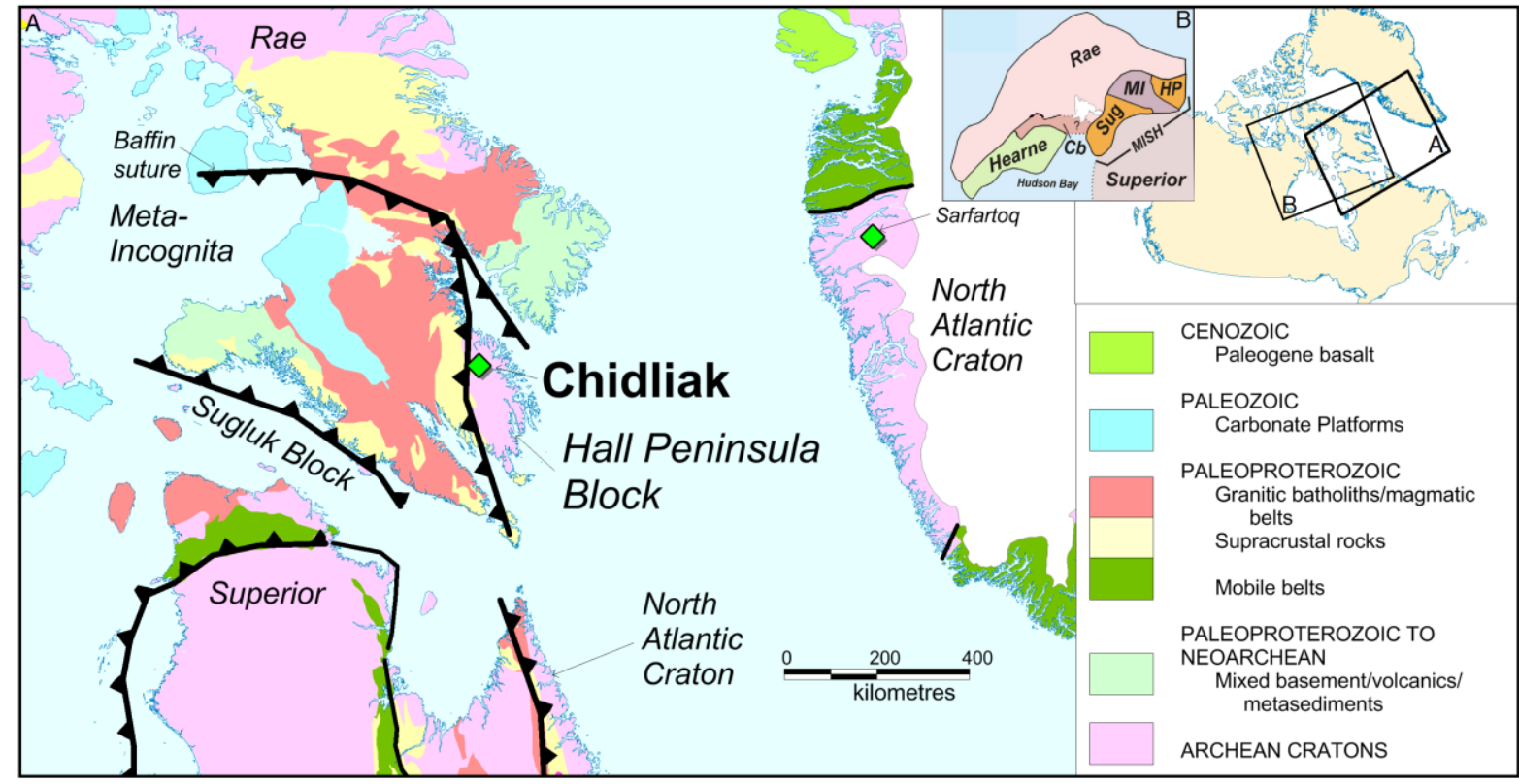

Fig. 1: Simplified geological map of the Canadian Shield and Western Greenland (from 11IKC-4578; Kopylova et al., 2017), modified from Chorlton (2007). Inset A, heavy black lines are faults with "teeth" showing the direction dip; Green diamonds mark the location of the Chidliak and Sarfartoq kimberlites, respectively. Inset $\mathrm{B}, \mathrm{Cb}-\mathrm{Committee}$ Bay belt, see text for other abbreviations.

\section{Samples and results}

The petrography, mineralogy, thermobarometry and whole rock chemistry of 120 peridotite and pyroxenite xenoliths from Chidliak kimberlites (pipes $\mathrm{CH}-1,-6,-7$, and -44) were comprehensively reported in 11IKC-4578 by Kopylova et al. (2017). A subset of 32 peridotite xenoliths were selected for Re-Os dating and PGE analysis in this study. The sample suite spans a range of compositions that typically reflect melt depletion and potential subsequent re-fertilization (e.g., olivine Fo $=88$ to 92.7 (Fig. 2) and 0.1 to 3.9 wt\% bulk rock $\mathrm{Al}_{2} \mathrm{O}_{3}$ content (Fig. 3)). Most of these samples show PGE concentrations that are typical of cratonic peridotites (e.g., $\mathrm{Ir}=1$ to $6.6 \mathrm{ppb}$, average $=3.3 \mathrm{ppb}$ ) with patterns ranging from P-PGE (Pd and Pt) depletion to slight enrichment relative to I-PGE (Os, Ir and $\mathrm{Ru})\left(\right.$ Fig. 4). The peridotites studied show variable Os isotopic compositions $\left({ }^{187} \mathrm{Os} /{ }^{188} \mathrm{Os}=0.1090\right.$ to 0.2124 ) corresponding to Re depletion model ages ( $\mathrm{T}_{\mathrm{RD}}$ at the time of eruption) ranging from $2.94 \mathrm{Ga}$ to present with a main mode in the Meso- the Neoarchean. 


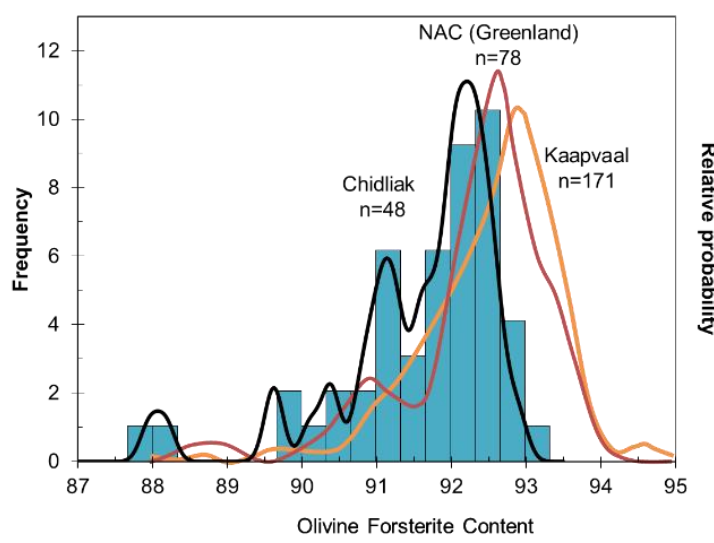

Fig. 2: Histogram of olivine forsterite content from the Chidliak peridotites. Also shown are the relative probability curves for olivine from Kaapvaal and NAC cratons (Pearson and Wittig, 2014).

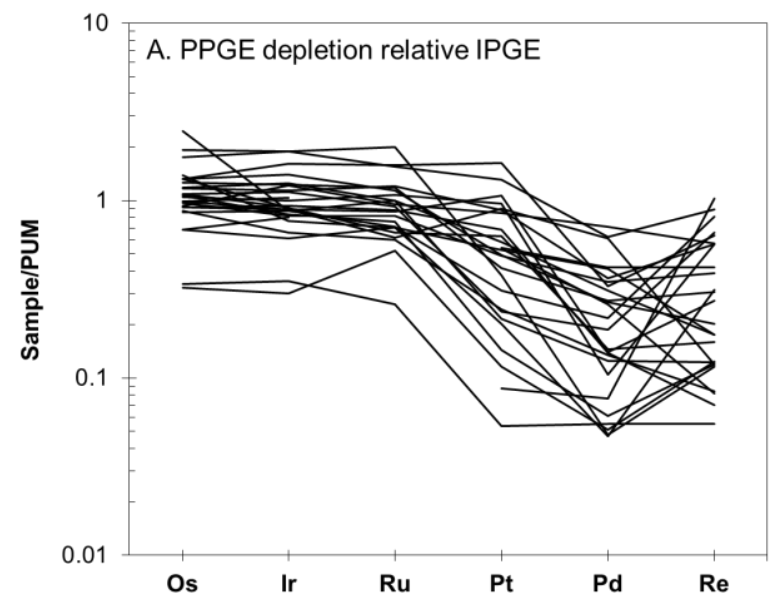

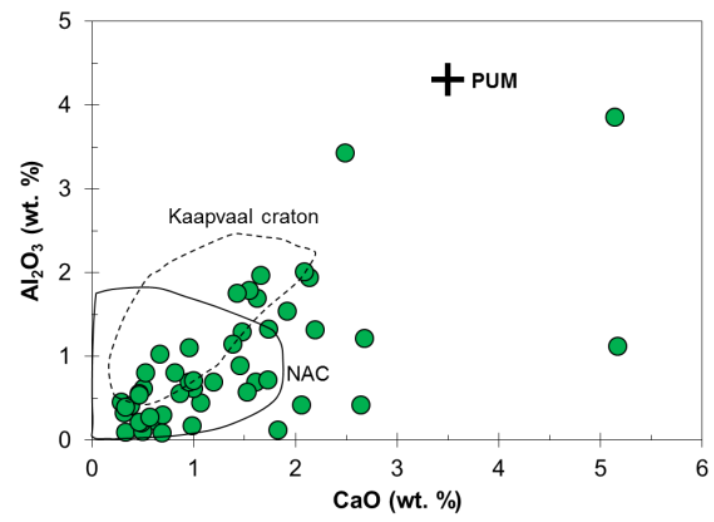

Fig. 3: Whole rock $\mathrm{CaO}$ vs $\mathrm{Al}_{2} \mathrm{O}_{3}$ contents of the Chidliak peridotites. Primitive Upper Mantle (PUM), Kaapvaal and NAC peridotite fields are shown for comparison.

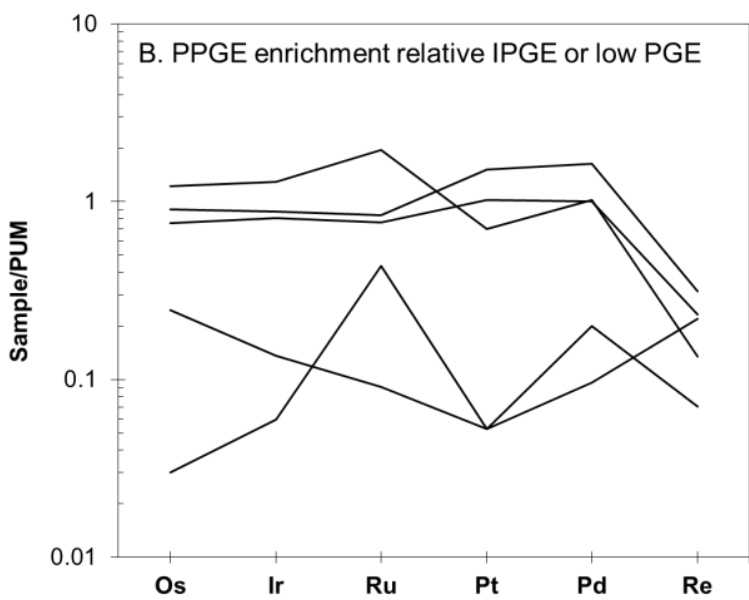

Fig. 4: PUM-normalized PGE patterns of the Chidliak peridotites. A. Main group showing PPGE (Pt \& Pd) depletion relative to IPGE (Os, Ir and Ru), often with Re enrichment; B. Sub-group showing PPGE enrichment relative to IPGE or low PGE contents.
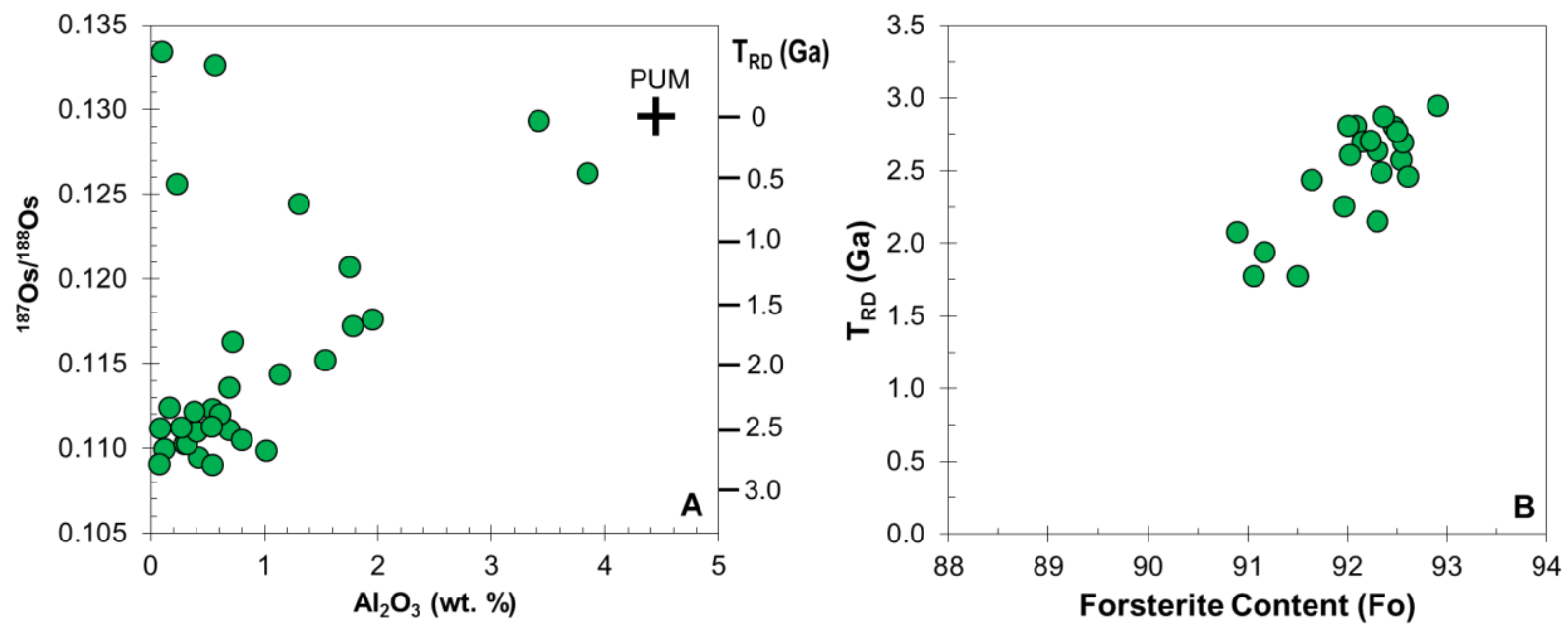

Fig. 5: A. Whole rock $\mathrm{Al}_{2} \mathrm{O}_{3}$ vs ${ }^{187} \mathrm{Os} /{ }^{188} \mathrm{Os}$ of Chidliak peridotites. B. Correlation between olivine forsterite content and $\mathrm{T}_{\mathrm{RD}}$ ages for samples with $\mathrm{T}_{\mathrm{RD}}$ greater than $1.7 \mathrm{Ga}$. 


\section{Discussion}

Among the 32 samples analyzed, 23 peridotites possessing variable P-PGE depletion patterns and $T_{R D}$ ages greater than $1.7 \mathrm{Ga}$ show strong correlations between $\mathrm{T}_{\mathrm{RD}}$ ages (or ${ }^{187} \mathrm{Os} /{ }^{188} \mathrm{Os}$ ) and melt depletion indicators (such as $\mathrm{Fo}, \mathrm{Al}_{2} \mathrm{O}_{3}, \mathrm{Pd} / \mathrm{Ir}$ and $\mathrm{Mg} / \mathrm{Si}$; Fig. 5), suggesting a common ancient melt depletion event of variable extent that produced depleted peridotite residues at ca. $3 \mathrm{Ga}$. The oldest $\mathrm{T}_{\mathrm{RD}}$ ages match the magmatic zircon ages of the oldest crust on the Hall Peninsula (e.g., From et al., 2016).

Given the absence of correlation between Fo or melt depletion indicators and depth (P) of equilibration (Kopylova et al., 2017), there is no general vertical depletion profile preserved in the Chidialk lithospheric mantle root. Osmium model ages remain close to $\sim 3$ Ga throughout the depth range of our samples (Fig. 5), and appear unaffected by the variety of fertility with depth. Given the lack of correlation between ${ }^{187} \mathrm{Os} /{ }^{188} \mathrm{Os}$ and metasomatic indicators $\left(\mathrm{Ca} / \mathrm{Al}\right.$, or $\mathrm{TiO}_{2}$ in garnet), the metasomatic event(s) appear to be recent. This is supported by the presence of elevated Re/Os ratios and P-PGE enriched patterns in samples still keeping ancient $\mathrm{T}_{\mathrm{RD}}$ ages, indicating low $\mathrm{Os}$ concentrations in the metasomatic agents, which may have stripped Os from, instead of adding Os to, the mantle lithosphere.

A few samples, derived predominantly from the deepest section of lithosphere $(>50 \mathrm{~kb})$ of the $\mathrm{CH}-1,-7$ and -44 mantle domains, have very variable PGE patterns, with ${ }^{187} \mathrm{Os} /{ }^{188} \mathrm{Os}$ ratios close to, or significantly greater than, modern mantle. These ratios are found only in Opx-free, Cpx-enriched samples or in sheared samples. The samples may represent cratonic lithosphere that was heavily overprinted by a high-Os agent, which may be related to varied types of metasomatism observed in Chidliak (Kopylova et al., 2017).

We conclude that the lithosphere beneath southern Baffin Island is cratonic in origin, with a broadly similar age spectrum and composition to that beneath western Greenland (Wittig et al., 2010). These observations support the view that the lithospheric mantle sampled by Chidliak kimberlites represents a portion of the North Atlantic cratonic mantle, with its distinct composition reflecting carbonatitic rather than silicic metasomatism (Kopylova et al., 2017).

\section{References}

Berman, R. G., Sanborn-Barrie, M., Rayner, N. \& Whalen, J. (2013). The tectonometamorphic evolution of Southampton Island, Nunavut: Insight from petrologic modeling and in situ SHRIMP geochronology of multiple episodes of monazite growth. Precambrian Research 232, 140-166.

Chorlton, L. (2007). Generalized geology of the world: bedrock domains and major faults in GIS format, Geological Survey of Canada Open File 5529.

Connelly, J. N., Thrane, K., Krawiec, A. W. \& Garde, A. A. (2006). Linking the Palaeoproterozoic Nagssugtoqidian and Rinkian orogens through the Disko Bugt region of West Greenland, Journal of The Geological Society 163, 2, 319-335.

From, R.E., Pearson, D. G., Luo, Y., (2016). U-Pb and Lu-Hf isotopes in complex zircon grains from eastern Hall Peninsula, Baffin Iland uisng laser ablation split stream inductively coupled mass spectroscopy (LASS-ICP MS).

Kopylova, M., Tso, E., Ma, F., Liu, J., Pearson, D. G. (2017). Peridotite xenoliths of the Chidliak kimberlite province (NE Canada): The thermally disturbed mantle of North Atlantic craton with local Ti-Na metasomatism. To be submitted for Journal of Petrology.

Pearson, D.G., Wittig, N. (2014). The formation and evolution of the subcontinental mantle lithosphere - evidence from mantle xenoliths. Treatise of Geochemistry, Volume 3: The Mantle and Core, Chapter 3.6, 255-292.

Scott, D. J. (1999). U-Pb geochronology of the eastern Hall Peninsula, southern Baffin Island, Canada: a northern link between the Archean of West Greenland and the Paleoproterozoic Torngat Orogen of northern Labrador. Precambrian Research 93, 5-26.

Wittig, N., Webb, M., Pearson, D.G., Dale, C.W., Ottley, C.J., Hutchison, M., Jensen, S.M., Luguet, A. (2010). Formation of the North Atlantic Craton: Timing and mechanisms constrained from ReOs isotope and PGE data of peridotite xenoliths from SW Greenland. Chemical Geology 276, 166187. 